\title{
Impact of Biocatalyst and Moisture Content on Toluene/Xylene Mixture Biofiltration
}

\author{
Eva Klapková ${ }^{1}$, Martin Halecký ${ }^{1}$, Mark Fitch ${ }^{2}$, Carlos Ricardo Soccol ${ }^{3}$ and Jan Paca ${ }^{1 *}$ \\ ${ }^{1}$ Institute of Chemical Technology; Department of Fermentation Chemistry and Bioengineering; Technicka 5, 160 \\ 28; jan.paca@vscht.cz; Prague - Czech Republic. ${ }^{2}$ Civil, Architectural and Environmental Engineering; University \\ of Missouri; Rolla - USA. ${ }^{3}$ Universidade Federal do Paraná; Centro Politécnico/Jardim das Américas, 19011; \\ 81531-970; soccol@ufpr.br; Curitiba - PR - Brasil
}

\begin{abstract}
The objective of this work was to determine the influence of microbial inoculation on degradation efficiency. Three biofilters were used for the treatment of waste gas. A mixture of compost and perlite (8:2) served as the packing material. One biofilter was inoculated with a constructed microbial population. The second remained uninoculated, having the natural population present in the compost. The third biofilter was uninoculated and the packing material was sterilized. The degradation ability of the uninoculated biofilter started to drop after 18 days, while the removal efficiency of inoculated biofilter was stable. The sterile biofilter proved to have no removal efficiency. Moisture content of the packing and ability of the packing to keep moisture was tested. The results showed a significant dependence of the degradation efficiency on the packing moisture content, with highest removal efficiency observed at $70 \%$ moisture content.
\end{abstract}

Key words: Biofiltration, constructed mixed population, moisture content, pollutant mixture

\section{INTRODUCTION}

Toluene and other monoaromatic compounds such benzene, ethylbenzene and xylenes (BTEX) are commonly found in gasoline-contaminated sites (EPA 1995). The presence of BTEX compounds in the environment is a major concern because of their toxicity (Matteau and Ramsay 1997). Biofiltration systems can effectively remove odours and volatile organic compounds (VOCs) from diluted air streams at a relatively low cost as compared with other alternatives. Biofilters can operate for several years with minimum maintenance. To sustain high removal efficiency, parameters such as water content, nutrient concentration, $\mathrm{pH}$, inlet air relative humidity, and temperature should be controlled (Morales et al., 2003). Biodegradation rates in the biofilm are limited either by microbial activity or contaminant diffusion through the biofilm and thus, in cases where diffusion is not limiting, biofilters with increased microbial activity should have a superior performance.

Moisture content of the biofilter bed is one of the most important parameters of biofiltration process. The optimum moisture of the packing based on compost is reported as between 40 and $60 \%$ (Morales at al., 2003, De Heyder et al., 1994). Bed moisture content of less than $40 \%$ causes a significant drop in the elimination capacity. The drying of the biofilter bed may be caused by low inlet gas humidity (lower than $100 \%$ ), changes of

\footnotetext{
* Author for correspondence
} 
inlet gas temperatures and heating of the biofilter bed by exothermic biodegradation processes or the sun or ambient temperature (Morales et al., 2003, Kinney et al., 1999). In contrast to low moisture, too high a moisture content leads to higher bed pressure drop, worse mass transfer (creation of zones with deficiency of oxygen, minerals and carbon and energy sources) and bed compaction (Abumaizar et al., 1998).

\section{MATERIALS AND METHODS}

A schematic diagram of the biofilter is shown in Fig. 1. The bioreactor was constructed of glass column $50 \mathrm{~cm}$ high with an internal diameter of 50 $\mathrm{mm}$. The packing material was a 8:2 mixture of compost and perlite. The packed bed height was the column's full $50 \mathrm{~cm}$, giving a reactor volume of $9.8 \cdot 10^{-4} \mathrm{~m}^{3}$.

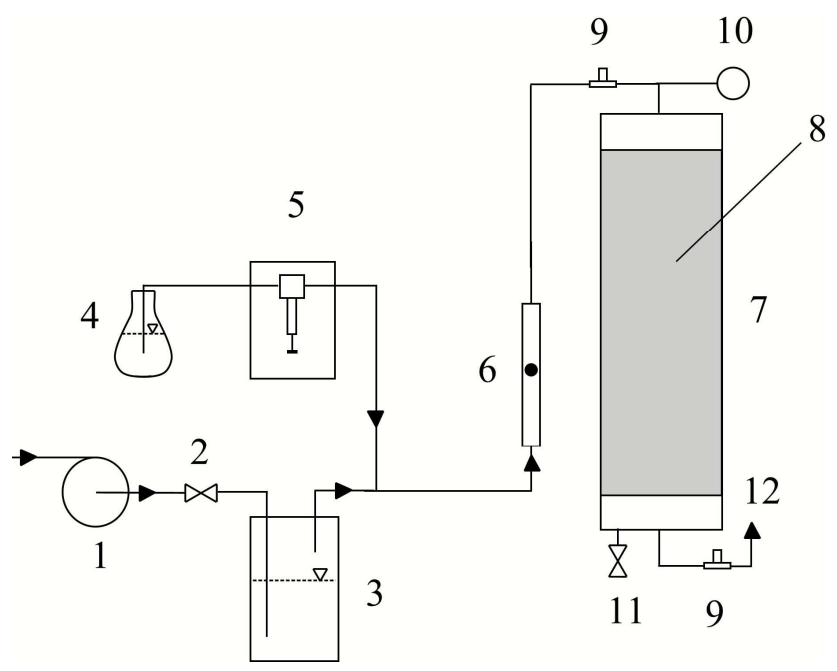

Figure 1 - Experimental set-up of biofilter system. 1 - blower, 2 - needle valve for flow rate control, 3 - humidification vessel, 4 - vessel with toluene and xylene, 5 - syringe pump, 6 rotameter, 7 - biofilter, 8 - packing, 9 - sampling ports, 10 - manometer, 11 - valve for leachate, 12 - outlet

The mixed microbial culture used to inoculate the biofilter was comprised of five species, including: Sphingobacterium multivorum ( $\mathrm{G}^{-}$rods), Comamonas testosteroni ( $\mathrm{G}^{-}$rods), Pseudomonas putida ( $\mathrm{G}^{-}$rods), Pseudomonas fluorescens $\left(\mathrm{G}^{-}\right.$ rods) and Chryseobacterium indologenes $\left(\mathrm{G}^{-}\right.$ rods). All the bacterial strains were primary toluene and xylene degraders (i.e. each strain was able to use the individual pollutants as the sole carbon and energy source for growth). The inoculation suspension was prepared using threestage submerged cultivations with toluene vapor as the sole carbon and energy source. The medium composition for cultivation consisted of $\left(\mathrm{g} . \mathrm{L}^{-1}\right)$ : $\mathrm{K}_{2} \mathrm{HPO}_{4} 4.3 ; \mathrm{KH}_{2} \mathrm{PO}_{4} 3.4 ; \mathrm{KNO}_{3} 2 ; \mathrm{MgCl}_{2}$. 6 $\mathrm{H}_{2} \mathrm{O} ; 0.34 ; \mathrm{FeSO}_{4} 6.10^{-4} ; \mathrm{Na}_{2} \mathrm{MoO}_{4} 1.10^{-5}$.

Key biodegradation experimental conditions included: temperature of $22^{\circ} \mathrm{C}$, a mineral medium (MM) for growth which contained $0.75 \mathrm{~g} / \mathrm{L}$ $\left(\mathrm{NH}_{4}\right)_{2} \mathrm{SO}_{4}, 0.37 \mathrm{~g} / \mathrm{L} \mathrm{KNO}_{3}, 0.1 \mathrm{~g} / \mathrm{L} \mathrm{NaCl}, 0.8 \mathrm{~g} / \mathrm{L}$
$\mathrm{K}_{2} \mathrm{HPO}_{4}, 0.6 \mathrm{~g} / \mathrm{L} \mathrm{KH} \mathrm{KH}_{4}, 0.34 \mathrm{~g} / \mathrm{L} \mathrm{MgCl}_{2} .6 \mathrm{H}_{2} \mathrm{O}$, and $1 \mathrm{~mL} / \mathrm{L}$ trace elements. Sterile $\mathrm{MM}$ was added once per week.

The synthetic waste gas influent included toluene and xylene (technical grade). The VOCs in the gas phase were measured using an Agilent $6890 \mathrm{~N}$ gas chromatograph equipped with an ultra alloy-5 (5 $\%$ phenylmethylsilicone) capillary column $30 \mathrm{~m}$ in length, $0.53 \mathrm{~mm}$ inner, and with a $1.5 \mu \mathrm{m}$ film thickness (Quadrex Corp., UA5 - 30V - 1.5 F, New Haven, CT). The carrier gas used was ultra high purity argon at a flow rate of $5 \mathrm{ml} \cdot \mathrm{min}^{-1}$. Detection was accomplished with a flame ionization detector (FID) with ultra high purity hydrogen and breathing quality air at flow rates of $28 \mathrm{ml} \cdot \mathrm{min}^{-1}$ and $315 \mathrm{ml} \cdot \mathrm{min}^{-1}$, respectively. GC operating conditions were: column temperature, $80^{\circ} \mathrm{C}$; FID temperature, $250^{\circ} \mathrm{C}$.

In this study, the following terms for performance calculations are defined as: 


\section{Elimination capacity}

$$
E C=\left(C_{\text {in }}-C_{\text {out }}\right) \cdot \frac{Q}{V_{b}} \quad\left(g_{c} \cdot m^{-3} \cdot h^{-1}\right)
$$

\section{Organic load}

$$
O L=C_{i n} \cdot \frac{Q}{V_{b}} \quad\left(g_{c} \cdot m^{-3} \cdot h^{-1}\right)
$$

\section{Removal efficiency}

$$
R E=\frac{E C}{O L} \cdot 100
$$

\section{Evolution rate of $\mathrm{CO}_{2}$}

$$
q_{\mathrm{CO}_{2}}=\left(C_{\text {in }}^{C O_{2(c)}}-C_{\text {out }}^{C O_{2(c)}}\right) \cdot \frac{Q}{V_{b}} \quad\left(g_{c} \cdot m^{-3} \cdot h^{-1}\right)
$$

$\mathrm{C}_{\mathrm{in}}, \mathrm{C}_{\text {out }}$ - inlet and outlet pollutant or $\mathrm{CO}_{2}$ concentration $\left(\mathrm{g}_{\mathrm{C}} \cdot \mathrm{m}^{-3}\right), \mathrm{Q}$ - air flow rate $\left(\mathrm{m}^{3} \cdot \mathrm{h}^{-1}\right)$, $\mathrm{V}_{\mathrm{b}}$ - filter bed volume $\left(\mathrm{m}^{3}\right)$.

Experiments were carried out with sterile air flow using input and output air filters (glass wool, filament diameter $0.015 \mathrm{~mm}$ ). The biofilters were loaded with a constant inlet concentration of $500 \pm$ $50 \mathrm{mg} \cdot \mathrm{m}^{-3}$ of both toluene and xylene (1:1 ratio). The air flow rate was kept constant at $0.5 \mathrm{~L} \cdot \mathrm{min}^{-1}$, giving a total organic loading of $30 \mathrm{~g}_{\mathrm{c}} \mathrm{m}^{-3} \mathrm{~h}^{-1}$.

\section{RESULTS AND DISCUSSION}

One biofilter was inoculated with the previously defined microbial culture; this biofilter was not sterilized prior to inoculation. The second one used only the natural microflora present in the compost packing medium. The third biofilter was sterilized.

Fig. 2a shows the removal efficiencies of all the biofilters. The sterile biofilter was not able to eliminate any toluene or xylene. RE during the first three days was caused just due to adsorption by the packing material. After that the RE decreased to zero.

The inoculated biofilter was able after three days to eliminate about $90 \%$ of the organic load. The removal efficiency remained fairly stable at about $85 \%$ during the whole time of experiment.

The second biofilter, with the natural microflora, showed a similar performance during the first thirty days of the experiment. Thereafter the RE decreased. Clearly the biocatalyst is a key parameter of the process. The inoculum prepared using toluene as the sole source of carbon and energy was able to metabolize organic loading for a longer period as compared to the natural microflora in the compost/perlite material. The induction of enzymes participating in metabolic pathways of aromatic hydrocarbons degradation is one of the major parameters of a successful biodegradation process. The decrease in RE is similar to that reported in other biofiltration studies (Devinny et al., 1999), which has been attributed to plugging of pore spaces (Marek et al., 1999).

The $\mathrm{CO}_{2}$ production during aromatics degradation is shown in Fig. 2b. The quantity of $\mathrm{CO}_{2}$ produced (as carbon) in some cases slightly exceeded the quantity of contaminant consumed (EC), given the carbon loading was $27.8 \mathrm{~g}_{\mathrm{c}} \mathrm{m}^{-3} \mathrm{~h}^{-1}$. Excess $\mathrm{CO}_{2}$ evolution may be due to endogenous decay of biomass. For steady-state degradation, a $100 \%$ mass balance of inlet and outlet carbon is expected. If not at steady state, the contaminant consumed is partly used as the carbon sources for microbial growth, which explains deficits in $\mathrm{CO}_{2}$ production. A second sink for carbon can be that as biodegradation takes place, the $\mathrm{CO}_{2}$ produced may accumulate in the biofilm as one of the carbonate species, $\mathrm{HCO}_{3}{ }^{-}, \mathrm{H}_{2} \mathrm{CO}_{3}$ or $\mathrm{CO}_{3}{ }^{2-}$ (Jorio et al., 2000, Jorio et al., 1998). The population naturally presented in compost used more carbon, probably for microbial growth, than the artificial prepared microbial population adapted for toluene. The effect of moisture content in the biofilter was tested. Contaminated air was humidified by bubbling through water before entering the biofilter but no water or mineral medium was added into biofilter. Two different air flow rates were used, $1 \mathrm{~L} \cdot \mathrm{min}^{-1}$ and $0.5 \mathrm{~L} \cdot \mathrm{min}^{-1}$. The higher air flow rate resulted in a more significant decrease of both the degradation efficiency (Fig. 4) and the packing moisture content (Fig. 3). The highest moisture content (about $70 \%$ ) gave the highest removal efficiency in the both air flow rates (Fig. 4). It should be noted that the effect of changes in time (biofilm aging) and removal efficiency cannot be separated. However, a very similar influence of the packing moisture content on removal efficiency was reported by Morales et al., 2003. They observed rapid decrease of degradation efficiency when packing moisture content dropped below $60 \%$. 

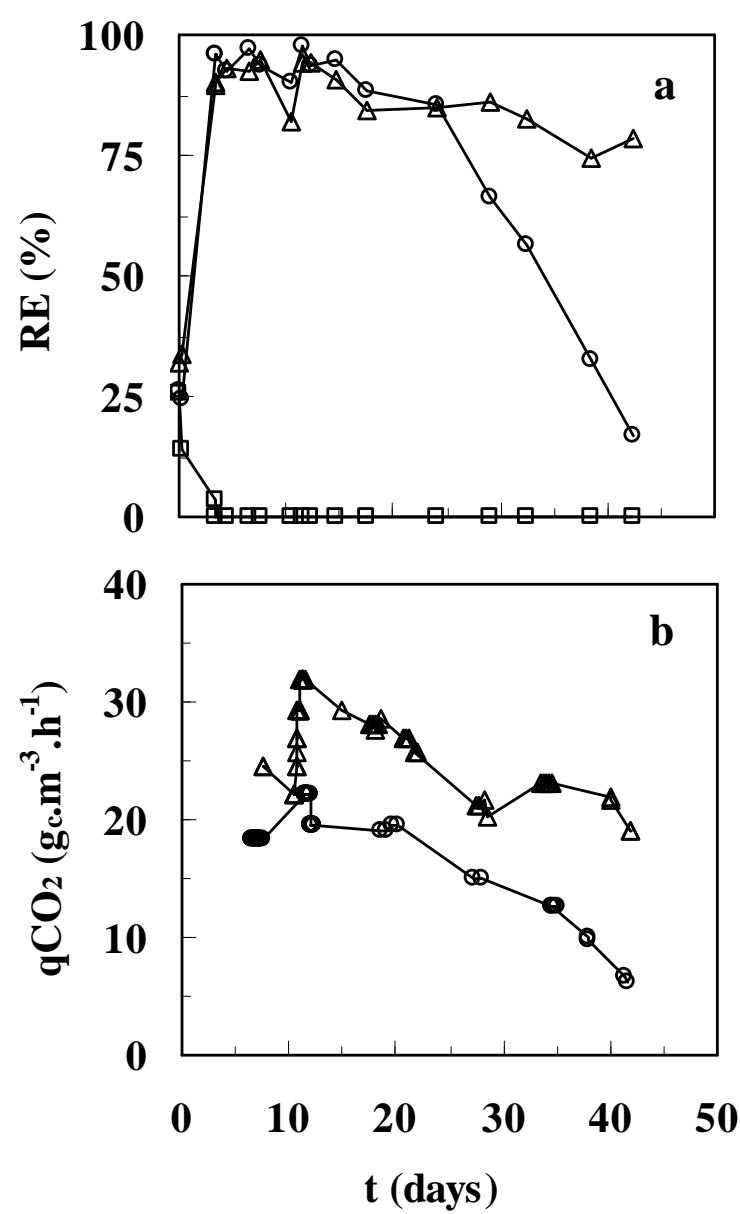

Figure 2 - Comparison of performance characteristics for the different biocatalysts. a - Removal efficiency, $\mathrm{b}-\mathrm{CO}_{2}$ evolution rates $\square$ - sterilized biofilter, $\circ$ - uninoculated biofilter, $\Delta$ inoculated biofilter

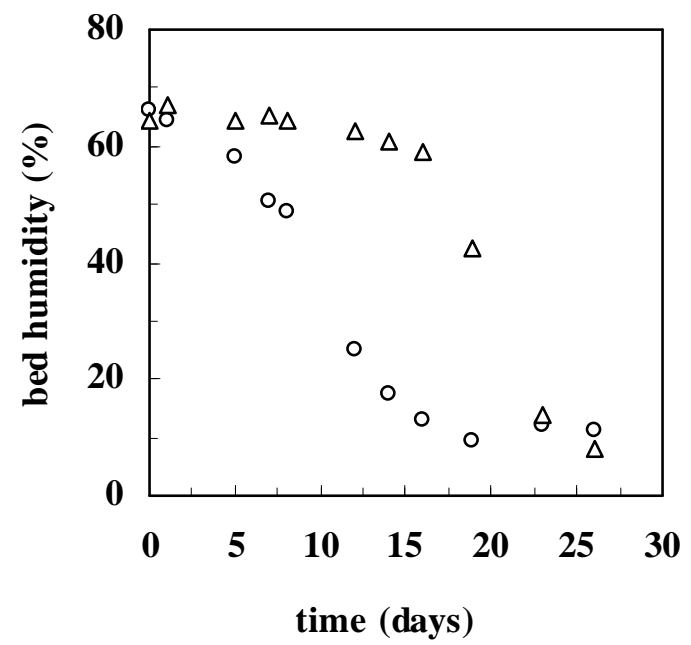

Figure 3 - Drying out of the packing at different air flow rates. $\circ$ - air flow rate of 1 L.min ${ }^{-1} \Delta-$ air flow rate of $0.5 \mathrm{~L} \cdot \mathrm{min}^{-1}$ 


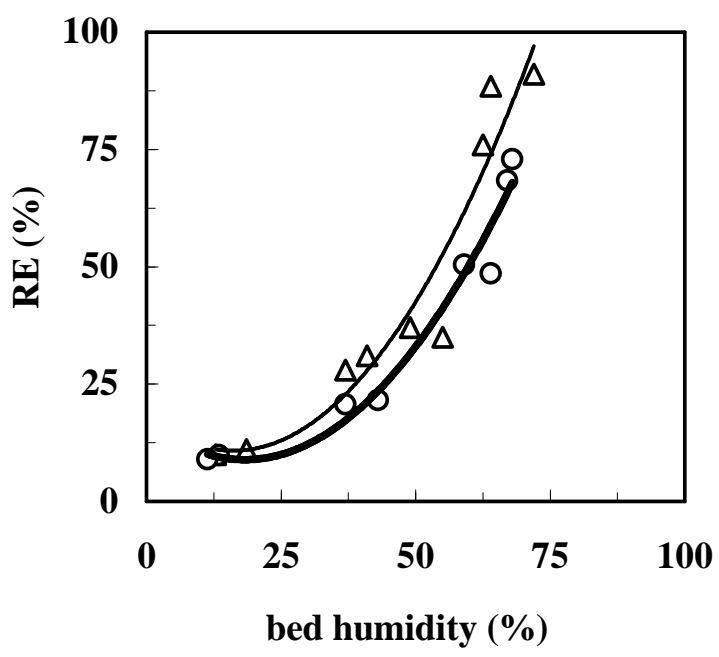

Figure 4 - Effect of the bed humidity on the performance characteristics.

\section{CONCLUSIONS}

No difference of the removal rate has been detected during the acclimation (first two weeks) for biofilters inoculated with the enrichment culture and that containing a natural compost microflora only. The microbial population prepared by cultivation with toluene as the sole source of carbon and energy had significant effcet on the long-term degradation of toluene and xylene. The induction of key enzymes is necessary for successful pollutant removal, and in this case the adapted inoculum performed better at longer term than the natural organisms present in the packing. The volumetric air flow rate in a biofilter also effects drying-out of the packing. A moisture content of about $70 \%$ was found to be optimal for effective process and plays an important role in reaching high values of removal efficiency.

\section{ACKNOWLEDGEMENTS}

The work was financially supported by the Czech Science Foundation, Join Project 104/05/0194 and by the Ministry of Education of the Czech Rep., Project MSM 6046137305.

\section{RESUMO}

O objetivo deste trabalho foi determinar a influência da inoculação microbiana na eficiência da degradação. Três biofiltros foram utilizados no tratamento do gás residuais. Uma mistura de composto e perlite na proporção $(8: 2)$ serviu como o material de empacotamento dos biofiltros. Um biofiltro foi inoculado com uma população microbial selecionada. $\mathrm{O}$ segundo permaneceu inoculado com a população microbiana natural presente no composto. O terceiro biofiltro foi inoculado com microrganismos selecionados com o material de empacotam previamente esterilizado. A capacidade de degradação do biofiltro não inoculado começou a se reduzir após 18 dias, enquanto que a eficiência da remoção do biofiltro se manteve estável. O biofiltro estéril não apresentou nenhuma eficiência na remoção dos compostos tóxicos. O grau de umidade do material e a característica do empacotamento foi avaliado. Os resultados mostraram uma dependência significativa da eficiência de degradação com o teor de umidade do material de empacotamento , a maior elevada remoção foi observada com $70 \%$ de índice de umidade. 


\section{REFERENCES}

Abumaizar, R. J.; Kocher, W. and Smith, E. H. (1998), Biofiltration of BTEX Contaminated Air Streams Using Compost-Activated Carbon Filter Media, Journal of Hazardous Materials, 60, 111-126.

Aizpuru, A.; Malhautier L.; Roux J. C. and Fanlo J. L. (2003), Biofiltration of a Mixture of Volatile Organic Compounds on Granular Activated Carbon. Biotechnology and Bioengineering, 83, 479-488.

De Heyder, B.; Overmeire, A.; Van Langenhove, H. and Verstraete, W. (1994), Ethene Removal from a Synthetic Waste Gas Using a Dry Biobed, Biotechnology and Bioengineering, 44, 642-648.

Devinny J. S.; Deshusses M. A. and Webster T. S. (1999), Biofiltration for Air Pollution Control. Boca Raton: Lewis Publ. pp. 255-258.

Jorio H.; Bibeau L. and Heitz M. (2000), Effects of Gas Flow Rate and Inlet Concentrations on Xylene Vapors Biofiltration Performance. Chemical Engineering Journal, 76, 209-221.

Jorio H.; Kiared K.; Brzezinski R.; Leroux A.; Viel G. and Heitz M. (1998), Treatment of Air Polluted with High Concentration of Toluene and Xylene in a PilotScale Biofilter. J. Chem. Biotechnol., 73, 183-196.

Kinney, K. A.; Loehr, R. C. and Cosi, R. L. (1999), Vapor-Phase Bioreactors: Avoiding Problems Through Better Design and Operation. Environmental Progress, 18, 222-230.

Marek J.; Páca J.; Koutský B. and Gerrard A.M. (1999), Determination of Local Elimination Capacities and Moisture Contents in Different Biofilters Treating Toluene and Xylene. Biodegradation, 10, 307-313.

Matteau Y. and Ramsay B. (1997), Active Compost Biofiltration of Toluene, Biodegradation, 8, 135-141.

Morales, M.; Hernández, S.; Cornabé, T.; Revah, S. and Auria, R. (2003), Effect of Drying on Biofilter Performance: Modeling and Experimental Approach, Environmental Sciency and Technology, 37, 985-992.

Received: September 09, 2004; Revised: February 22, 2005; Accepted: December 19, 2005. 